\title{
Pemilihan Angkutan Mudik Lebaran Menggunakan Metode Analytic Hierarchy Process
}

\author{
Narti $^{1}$, Ahmad Yani ${ }^{2}$, Adika Dharma Setiyadi ${ }^{3}$ \\ ${ }^{1}$ Sistem Informasi, STMIK Nusa Mandiri \\ narti.nrx@nusamandiri.ac.id \\ ${ }^{2}$ Sistem Informasi, Universitas Bina Sarana Informatika, \\ ahmad.amy@bsi.ac.id \\ ${ }^{3}$ Sistem Informasi, STMIK Nusa Mandiri \\ dharmadika153@gmail.com
}

\begin{abstract}
Public transportation is the movement of people or goods from one place to another by using vehicles that are moved by humans or machines. In the selection of public transportation back and forth it is sometimes difficult to determine suitable transportation for use in this case the community can be assisted with a method of decision support systems, one of which is the Process Hierarchy Analysis (AHP). AHP itself is a method that breaks down complex, unstructured situations, and organizes parts or variables into a hierarchical form. in determining decisions using the AHP method the community can determine which transportation is more important by giving a predetermined level of importance. In this study four criteria were used namely price, service, quality and purpose of travel. In this study four alternatives were also taken, including bus, plane, fire train and sea boat. With this research, it is expected to be able to help and facilitate the community in choosing the right vehicles for going home at Lebaran.
\end{abstract}

Keywords: Decision Support System, Analytic Hierarchy Process, Transportation.

\section{PENDAHULUAN}

Transportasi merupakan perpindahan tubuh atau benda dari suatu tempat ke tempat lain. Transportasi sendiri dibagi menjadi tiga bagian, transportasi darat, transportasi laut dan juga transportasi udara. "Transportasi adalah kegiatan pemindahan barang dan manusia dari tempat asal ke tempat tujuan. Dalam kegiatan transportasi diperlukan empat komponen yakni : tersedianya muatan yang diangkut, terdapatnya kendaraan sebagai sarana angkutannya, adanya jalan yang yang dapat dilaluinya dan tersedianya terminal." menurut Raharjo Adisasmita dalam (Jusna \& Nempung, 2016). Transportasi sangat diandalkan oleh masyarakat luas yang akan berpergian dekat mapun jauh, seperti saat akan melakukan mudik lebaran, masyarakat berbondong-bondong mencari transportasi mudik lebaran yang akan mereka gunakan saat mudik

Dengan banyaknya minat penggunaan moda transportasi umum saat mudik lebaran juga harus diimbangi dengan jumlah transportasi yang beroperasi untuk mengangkut penumpang maupun barang bawaannya, serta fasilitas yang tersedia yang digunakan oleh pemudik lebaran, mulai dari kesiapan transportasi yang beroperasi dan juga kesiapan jalur atau rute yang digunakan. Dengan siapnya sarana dan prasarana yang digunakan saat mudik lebaran ini akan menjadi dampak positif bagi pemudik yang menggunakan transportasi tersebut, hal tersebut akan mengurangi rasa keresahan masyarakat saat akan menjalankan mudik lebaran yang selama ini manjadi kendala bagi masyarakat untuk menjalankan mudik atau mengurungkan niatnya untuk melakukan mudik karena berbagai alasan kesiapan aspek perjalanan.

Selama ini masyarakat daerah Legok, Tangerang yang memiliki kampung halaman di daerah jawa khusunya jawa tengah banyak yang bingung dalam memilih alat transportasi mudik lebaran, pasalnya ketika mereka sudah memilih trasportasi mudik, mereka ingin memilih yang lain namun masih ragu untuk mencoba karena khawatir akan kurang efektif dan efesien serta tidak lebih nyaman dari yang pernah dicoba.

Dengan adanya masalah di atas, penulis terpacu untuk melakukan penelitian dengan mencari keputusan dalam memilih alat transportasi umum untuk mudik lebaran menggunakan Sistem Penunjang Keputusan (SPK) salah satunya menggunakan metode AHP agar dapat ditentukan alat transportasi mana yang lebih tepat untuk digunakan sebagai angkutan mudik lebaran.

"Sistem Pendukung Keputusan (SPK) adalah bagian sistem informasi berbasis komputer yang dipakai untuk mendukung pengambilan keputusan dalam suatu organisasi atau perusahaan" Menurut Sri Kumaladewi dan Hari Purnomo dalam (Sitio, 2017) "SPK adalah sistem yang dapat memberikan kemampuan memecahkan masalah ataupun kemampuan pengkomunikasian masalah dengan suatu kondisi" (Priyono \& Utami, 2018) 
"Sistem Pendukung Keputusan (SPK) memadukan sumber daya inteltual dari individu dengan kapabilitas komputer untuk meningkatkan kualitas keputusan. SPK adalah sistem pendukung berbasis komputer bagi para pngambil keputusan managemen mengenai masalah masalah tidak terstruktur" (Septiani \& Siahaan, 2017)

"Analytic Hierarchy Process (AHP) pada dasarnya, proses pengambilan keputusan adalah memilih suatu alternatif. Peralatan utama AHP adalah sebuah hirarki fungsional dengan input utamanya adalah presepsi manusia. Keberadaan hirarki memungkinkan dipecahnya masalah kompleks atau tidak terstruktur dalam sub-sub masalah, lalu menyusun menjadi sebuah hirarki" Kusrini dalam (Sitio, 2017)

"Penelitian ini dilakukan untuk mengetahui kesiapan transportasi dalam memenuhi dan menunjang kebutuhan para pemudik yang akan melaukan mudik atau pulang kampung halaman, menggunakan jasa angkutan umum juga kesiapan pemerintah dalam menyelesaikan persoalan yang terus terjadi saat mudik lebaran, dari mulai menyelesaikan persoalan arus lalu lintas yang akan dilalui pemudik, juga infrastuktur yang layak demi keselamatan dan kenyamanan para pemudik dalam perjalanan ke kampung halaman masing-masing. Dalam hal ini pemudik juga harus bijak dalam menentukan pilihan mereka dalam menggunakan transportasi yang sesuai dengan keinginan." (Achmad Wirabrata, 2014)

"Metode Analytical Hierarchy Process (AHP) ini mampu menghasilkan hasil yang lebih konsisten serta yang dihasilkan adalah berdasarkan urutan ranking dari setiap alternatif yang ada"(Narti, Sriyadi, Rahmayani, \& Syarif, 2019)

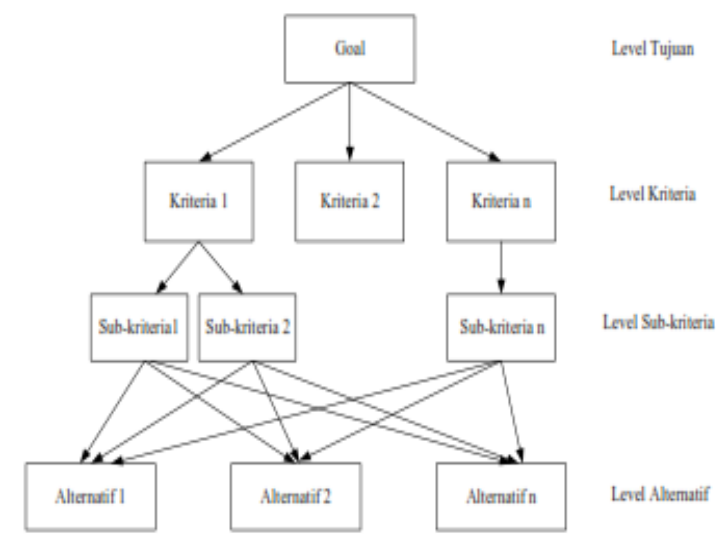

Sumber : ( Basuki \& Andharini, 2016)

Gambar 1. Struktur Hirarki AHP

\section{METODOLOGI PENELITIAN}

\section{Tahapan Penelitian}

A.Tahapan Perencanaan

Dalam tahap ini penulis menentukan tema Sistem pendukung keputusan pemilihan transportasi mudik dengan menggunakan metode Analytic Hierarchy Process (AHP) dengan langkahlangkah sebagai berikut :

1. Mengidentifikasi dan Merumuskan Masalah dalam tahap ini penulis mengidentifikasi dan merumuskan masalah apa yang terjadi dimasyarakat dalam menentukan pemilihan moda transportasi mudik dan menentukan metode apa yang akan digunakan dalam memecahkan masalah.

2. Melakukan studi Pendahuluan dalam tahap ini merncari sumber-sumber yang terkait dengan tema penelitian yang mana nantinya akan di jadikan sumber referensi bagi penulis dalam melakukan penelitian

3. Merumuskan Hipotesis melakukan dugaandugaan sementara yang nantinya akan diuji kebenarannya.

4. Merumuskan hasil penelitian yang kemudian dilanjutkan dengan menyusun hasil penelitian.

B. Tahapan Pelaksanaan

Dalam tahap ini penulis melakukan pengumpulan data-data yang terkait dengan yang didapatkan berdasarkan sampel yang telah dipilih, kemudian menentukan instrumen untuk menetapkan variabel yang jelas dan terukur. Instrumen ini sendiri penulis menggunakan sebuah kuesioner yang di bagikan ke sampel dan juga melakukan wawancara serta observasi di lapangan. Yang selanjutnya hasil dari intrumen itu akan menjawab dari rumusan masalah dan juga hipotesis dengan menggunakan metode yang telah ditentukan dalam menentukan pengambilan keputusan untuk memberikan hasil secara detail dalam pembahasan.

C. Tahapan Penulisan Laporan

Ditahap ini yang merupakan tahap final atau akhir, penulis menarik sebuah kesimpulan dari pembahasan yang telah disampaikan dari hasil penelitian-penelitian yang telah dilakukan dan kemudian membuat laporan penulisan dari bahan-bahan atau data-data yang telah dikumpulkan.

\section{Instrumen Penelitian}

semua alat yang digunakan untuk memeriksa, mengumpulkan dan menyelidiki suatu masalah atau menggolah, mengumpulkan, menganalisa dan menyajikan data secara sistematis serta secara objektif dengan tujuan memecahkan suatu persoalan atau menguji suatu hipotesis merupakan Instrumen penelitian.

Instumen atau alat yang digunakan oleh penulis dalam penelitian ini adalah kuesioner, wawancara dan juga observasi. Kuesioner yang digunakan oleh penulis ini bersifat tertutup dan tidak untuk dipublikasi, karena pertanyaan dan jawaban telah di sediakan oleh penulis, sedangkan responden hanya diminta untuk mengisi sesuai dengan petunjuk 
pengisian.

Penginputan data dalam penelitian ini termasuk skala ratio, karena data penelitian ini berupa perbandingan berpasangan antara kriteria-kriteria dan juga aternatif dari setiap pertanyaan yang kemudian dinilai dengan skala perbandingan berpasangan dari mulai skala 1 sampai dengan 9 dari setiap masing-masing pertanyaan.

\section{Sampel Penelitian}

Dikarenakan populasi di kecamatan legok sangat luas dan banyak, juga waktu yang tersedia sangat terbatas, maka penulis menggunakan sampel sebagai penelitian. sebagian objek yang diambil dari keseluruhan objek yang diteliti dan dianggap mewakili seluruh populasi disebut Sampel. Penulis menggunakan probability sampling atau random sample adalah metode pengambilan sampel secara random atau acak, dengan cara pengambilan sampel ini seluruh anggota populasi diasumsikan memiliki kesempatan yang sama untuk terpilih menjadi sampel penelitian. Dalam probability sampling teknik yang digunakan adalah cluster random sampling, adalah teknik sampling secara berkelompok, pengambilan sampel ini berdasarkan kelomok atau area tertentu. Penulis menggunakan teknk ini karena kecamatan legok sangat luas terdiri dari 10 desa dan 1 kelurahan, maka sampel yang akan digunakan adalah masyarakat desa legok dengan 32 sampel sebagai responden yang mewakili seluruh kecamatan legok.

Tabel1. Skala Penilaian Perbandinga Berpasangan

\begin{tabular}{|c|c|c|}
\hline $\begin{array}{c}\text { Itensitas } \\
\text { Kepentingan }\end{array}$ & Keterangan & Penjelasan \\
\hline 1 & $\begin{array}{l}\text { Kedua elemen } \\
\text { sama pentingnya }\end{array}$ & $\begin{array}{l}\text { Dua elemen } \\
\text { mempunyai } \\
\text { pengaruh yang } \\
\text { sama besar terhadap } \\
\text { tujuan }\end{array}$ \\
\hline 3 & $\begin{array}{l}\text { Elemen yang satu } \\
\text { sedikit lebih } \\
\text { penting daripada } \\
\text { lainnya }\end{array}$ & $\begin{array}{l}\text { Pengalaman dan } \\
\text { penilaian sedikit } \\
\text { menyongong satu } \\
\text { elemen dibanding } \\
\text { elemen lainnya }\end{array}$ \\
\hline 5 & $\begin{array}{l}\text { Elemen yang satu } \\
\text { lebih penting } \\
\text { daripada lainnya }\end{array}$ & $\begin{array}{l}\text { Pengalaman dan } \\
\text { penilaian sangat } \\
\text { kuat menyongong } \\
\text { satu elemen } \\
\text { dibanding elemen } \\
\text { lainnya }\end{array}$ \\
\hline 7 & $\begin{array}{l}\text { Elemen satu jauh } \\
\text { lebih penting } \\
\text { daripada lainnya }\end{array}$ & $\begin{array}{l}\text { Satu elemen yang } \\
\text { kuat disongkong } \\
\text { dan dominan } \\
\text { terlihat dalam } \\
\text { praktek }\end{array}$ \\
\hline 9 & $\begin{array}{l}\text { Satu elemen } \\
\text { mutlak penting } \\
\text { daripada elemen } \\
\text { lainnya }\end{array}$ & $\begin{array}{l}\text { memiliki tingkat } \\
\text { penegasan tertinggi } \\
\text { yang mungkin } \\
\text { menguatkan }\end{array}$ \\
\hline $2,4,6,8$ & $\begin{array}{l}\text { Nilai-nilai antara } \\
\text { dua pertimbangan } \\
\text { yang berdekatan }\end{array}$ & $\begin{array}{l}\text { Nilai ini diberikan } \\
\text { bila ada kompromi } \\
\text { antra dua pilihan }\end{array}$ \\
\hline Kebalikan & \multicolumn{2}{|c|}{$\begin{array}{l}\text { Jika untuk aktivitas i mendapat satu angka } \\
\text { dibanding dengan aktivitas } \mathrm{j} \text { maka } \mathrm{j} \\
\text { mempunyai nilai keblikannya dibanding } \mathrm{i}\end{array}$} \\
\hline
\end{tabular}

Sumber : (Priyono \& Utami, 2018)

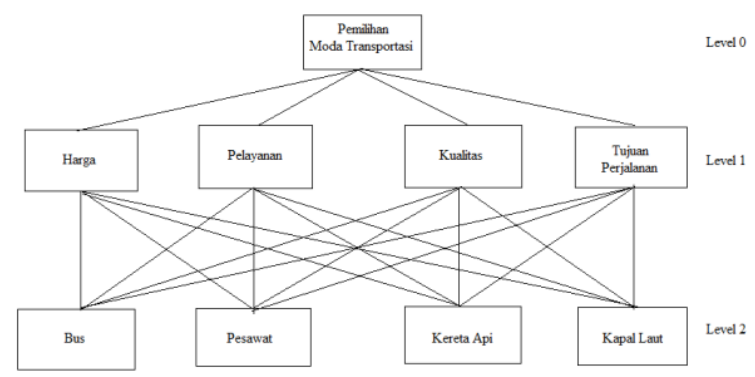

Gambar 2. Struktur Hirarki Pemilihan Moda Transportasi Mudik

Tabel2.TabelPenjelasanHirarkiKriteriaUtama

\begin{tabular}{|c|lr|}
\hline Kriteria & \multicolumn{1}{|c|}{ Penjelasan } \\
\hline Harga & $\begin{array}{l}\text { Harga yang dimaksudadalahhargadaritiket } \\
\text { yang diberikanolehpihaktransportasi yang } \\
\text { sesuaidenganbugdet }\end{array}$ \\
\hline Pelayan & $\begin{array}{l}\text { Pelayanan } \\
\text { dimaksuddisiniadalahpelayananaksespembelian } \\
\text { tiket,fasilitastransportasidankenyamanasaatber } \\
\text { kendara }\end{array}$ \\
\hline $\begin{array}{c}\text { Kualita } \\
\text { s }\end{array}$ & $\begin{array}{l}\text { Kualitas } \\
\text { dimaksuddisiniadalahkondisiataukelayakanken } \\
\text { daraandankeamanankendaraan }\end{array}$ \\
\hline $\begin{array}{c}\text { Tujuan } \\
\text { Perjalan } \\
\text { an }\end{array}$ & $\begin{array}{l}\text { Tujuanperjalananadalahkota } \\
\text { akandiujudanbisadijangkaumenggunaantranspo } \\
\text { rtasitersebut. }\end{array}$ \\
\hline
\end{tabular}

Tabel3.MatriksPerbandinganKriteriaUtama

\begin{tabular}{|l|l|l|l|l|}
\hline KriteriaUtama & Harga & Pelayanan & Kualitas & Tujuan \\
\hline Harga & 1,000 & 1,523 & 1,154 & 1,747 \\
\hline Pelayanan & 0,657 & 1,000 & 0,935 & 1,084 \\
\hline Kualitas & 0,867 & 1,070 & 1,000 & 1,076 \\
\hline Tujuan & 0,572 & 0,923 & 0,929 & 1,000 \\
\hline
\end{tabular}

Tabel 4. Matriks Perbandingan Kriteria Harga

\begin{tabular}{|c|c|c|c|c|}
\hline Kriteria & Bus & Pesawat & $\begin{array}{c}\text { Kereta } \\
\text { Api }\end{array}$ & $\begin{array}{c}\text { Kapal } \\
\text { Laut }\end{array}$ \\
\hline Bus & 1,000 & 1,538 & 0,928 & 1,358 \\
\hline Pesawat & 0,650 & 1,000 & 0,536 & 0,954 \\
\hline Kereta Api & 1,078 & 1,866 & 1,000 & 1,242 \\
\hline Kapal Laut & 0,736 & 1,408 & 0,805 & 1,000 \\
\hline
\end{tabular}

Tabel 5. Matriks Perbandingan Kriteria Pelayanan

\begin{tabular}{|c|c|c|c|c|}
\hline Kriteria & Bus & Pesawat & $\begin{array}{c}\text { Kereta } \\
\text { Api }\end{array}$ & $\begin{array}{c}\text { Kapal } \\
\text { Laut }\end{array}$ \\
\hline Bus & 1,000 & 0,478 & 0,557 & 0,925 \\
\hline Pesawat & 2,092 & 1,000 & 0,987 & 1,107 \\
\hline Kereta Api & 1,798 & 1,013 & 1,000 & 1,098 \\
\hline Kapal Laut & 1,081 & 0,903 & 0,911 & 1,000 \\
\hline
\end{tabular}

Tabel 6. Matriks Perbandingan Kriteria Kualitas

\begin{tabular}{|c|c|c|c|c|}
\hline Kriteria & Bus & Pesawat & $\begin{array}{c}\text { Kereta } \\
\text { Api }\end{array}$ & $\begin{array}{c}\text { Kapal } \\
\text { Laut }\end{array}$ \\
\hline
\end{tabular}


Paradigma - Jurnal Informatika dan Komputer,

Vol. 22 No 1, Maret 2020

P-ISSN 1410-5063, E-ISSN: 2579-3500

\begin{tabular}{|c|c|c|c|c|}
\hline Bus & 1,000 & 0,517 & 0,532 & 0,638 \\
\hline Pesawat & 1,934 & 1,000 & 0,881 & 1,084 \\
\hline Kereta Api & 1,880 & 1,135 & 1,000 & 1,042 \\
\hline Kapal Laut & 1,567 & 0,923 & 0,960 & 1,000 \\
\hline
\end{tabular}

4. Tujuan Perjalanan

2. Alernatif Berdasarkan Kriteria Harga

Iterasi Ke-1, matriks hasil perbandingan berpasangan berdasarkan kriteria harga di kuadratkan sebagai berikut :

Tabel 7. Matriks Perbandingan Kriteria Tujuan Perjalanan

\begin{tabular}{|l|l|l|l|l|}
\hline Kriteria & Bus & Pesawat & $\begin{array}{l}\text { Kereta } \\
\text { Api }\end{array}$ & $\begin{array}{l}\text { Kapal } \\
\text { Laut }\end{array}$ \\
\hline Bus & 1,000 & 0,943 & 0,993 & 0,843 \\
\hline Pesawat & 1,060 & 1,000 & 0,824 & 1,018 \\
\hline Kereta Api & 1,007 & 1,214 & 1,000 & 0,955 \\
\hline Kapal Laut & 1,186 & 0,982 & 1,047 & 1,000 \\
\hline
\end{tabular}

Untuk menentukan bobot atau prioritas menggunakan cara persamaan matriks, yaitu dengan cara mengkuadratkan hasil persamaan matriks kemudian dilakukan normalisasi sampai dengan syarat nilai eigen tidak berubah sampai 3 angka dibelakang koma, berikut adalah cara penyelesaian dengan persamaan matriks.

1. Kriteria Utama

Iterasi Ke-1, matriks hasil perbandingan berpasangan berdasarkan kriteria utama di kuadratkan sebagai berikut :

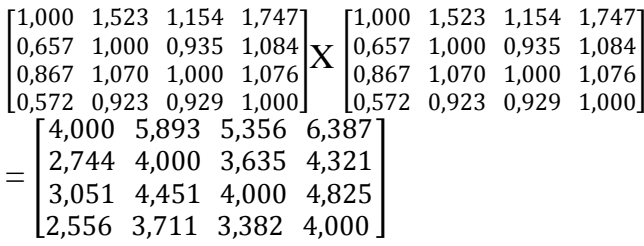

Kemudian menjumlahkan setiap baris matriks perbandingan lalu menghitung nilai eigen untuk normalisasi sebagai berikut :

\section{Total Baris Viktor Eigen}

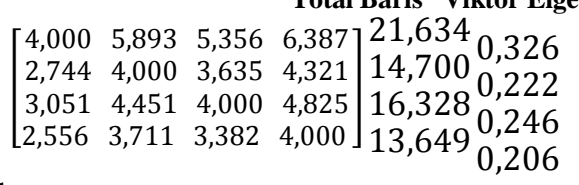

Jumlah $\quad 66,311 \quad 1,000$

Dari hasil data diatas untuk kriteria utama dilakukan perhitungan manipulasi matriks perbandingan untuk memenuhi syarat nila eigin tidak berubah 3 angka di belakang koma. Dari viktor eigen tersebut terlihat bahwa sebagai berikut :
a. Kiteria harga memiiki prioritas pertama dengan nila eigen 0,326
b. Kriteria pelayanan memiliki prioritas ketiga dengan nilai eigen 0,222
c. Kriteria kualitas memiliki proritas kedua dengan nilai eigen 0,246
d. Kriteria tujuan memiliki prioritas terakhir atau keempat dengan nilai eigen 0,206
Jadi, urutan pemilihan moda transportasi mudik berdasarkan kriteria yang ada adalah sebagai berikut :
1. Harga
2. Kualitas
3. Pelayanan

$\left[\begin{array}{llll}1,000 & 1,538 & 0,928 & 1,358 \\ 0,650 & 1,000 & 0,536 & 0,954\end{array}\right]\left[\begin{array}{llll}1,000 & 1,538 & 0,928 & 1,358 \\ 0,650 & 1,000 & 0,536 & 0,954\end{array}\right]$

$\begin{array}{llll}0,650 & 1,000 & 0,536 & 0,954 \\ 1,078 & 1,866 & 1,000 & 1,242\end{array} \times\left[\begin{array}{llll}1,000 & 1,538 & 0,928 & 1,358 \\ 0,650 & 1,000 & 0,536 & 0,954 \\ 1,078 & 1,866 & 1,000 & 1,242\end{array}\right.$

$\begin{array}{llll}1,078 & 1,866 & 1,000 & 1,242\end{array} \times\left[\begin{array}{llll}1,078 & 1,866 & 1,000 & 1,242\end{array}\right.$

$\left.\begin{array}{llll}0,736 & 1,048 & 0,805 & 1,000\end{array}\right] \quad\left[\begin{array}{llll}1,0,736 & 1,048 & 0,805 & 1,000\end{array}\right]$

$\left[\begin{array}{llll}4,000 & 6,231 & 3,774 & 5,336\end{array}\right]$

$=\begin{array}{llll}2,580 & 4,000 & 2,443 & 3,457\end{array}$

$=\left[\begin{array}{llll}2,580 & 4,000 & 2,443 & 3,457 \\ 3,022 & 6,691 & 4,000 & 5,727\end{array}\right.$

$\left[\begin{array}{llll}4,022 & 4,731 & 2,856 & 4,000\end{array}\right]$

Kemudian menjumlahkan setiap baris matriks perbandingan lalu menghitung nilai eigen untuk normalisasi sebagai berikut :

\section{Total Baris Viktor Eigen}

$$
\left[\begin{array}{llll}
4,000 & 6,231 & 3,774 & 5,336 \\
2,580 & 4,000 & 2,443 & 3,457 \\
4,271 & 6,691 & 4,000 & 5,727 \\
3,022 & 4,731 & 2,856 & 4,000
\end{array}\right] \begin{array}{ll}
19,340 & 0,288 \\
20,701 & 0,186 \\
14,629 & 0,308 \\
0,218
\end{array}
$$

Jumlah 67,130

\section{1,000}

Dari hasil diatas untuk alternatif berdasarkan kriteria harga dilakukan perhitungan manipulasi matriks perbandingan untuk memenuhi syarat nila eigin tidak berubah 3 angka di belakang koma. Dari viktor eigen tersebut terlihat bahwa sebagai berikut :

a. Bus memiliki prioritas kedua dengan nilai eigen 0,288

b. Pesawat memiliki proritas terakhir dengan nilai eigen 0,186

c. Kereta Api memilki peroritas terbanyak dengan nilai eigen 0,308

d. Kapal Laut memiliki prioritas ketiga dengan nilai eigen 0,218

jadi, urutan pemilihan moda transportasi mudik berdasarkan kriteria Harga adalah sebagai berikut :
1. Kereta Api
2. Bus
3. Kapal laut
4. Pesawat

3. Alernatif Berdasarkan Kriteria Pelyanan

Iterasi Ke-1, matriks hasil perbandingan berpasangan berdasarkan kriteria Pelayanan di kuadratkan sebagai berikut :

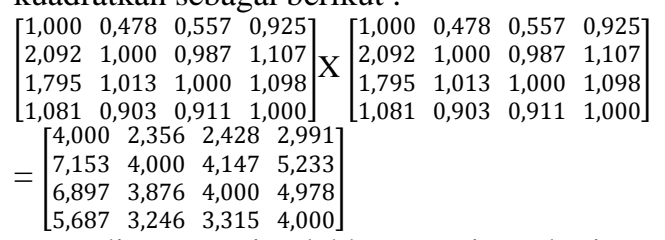

\begin{tabular}{|c|c|c|c|}
\hline Total Baris & & Vikto & $r$ Eigen \\
\hline$[4,000$ & 2,356 & 2,428 & $2,991]^{11,775} 0,172$ \\
\hline 7,153 & 4,000 & 4,147 & \begin{tabular}{l|l}
5,233 & 20,533 \\
\end{tabular} \\
\hline 6,897 & 3,876 & 4,000 & \begin{tabular}{l|l}
4,978 & 19,752 \\
\end{tabular} \\
\hline [5,687 & 3,246 & 3,315 & $4,000]_{16,249}^{0,239}$ \\
\hline Jumlah & 3,309 & & 1,000 \\
\hline
\end{tabular}

Kemudian menjumlahkan setiap baris matriks perbandingan lalu menghitung nilai eigen untuk normalisasi sebagai berikut : 
Dari hasil diatas untuk alternatif berdasarkan kriteria Pelayanan dilakukan perhitungan manipulasi matriks perbandingan untuk memenuhi syarat nila eigin tidak berubah 3 angka di belakang koma. Dari viktor eigen tersebut terlihat bahwa sebagai berikut :

a. Bus memiliki prioritas terakhir dengan nilai eigen 0,172

b. Pesawat memiliki proritas petama dengan nilai eigen 0,301

c. Kereta Api memiliki prioritas kedua dengan nilai eigen 0,289

d. Kapal laut memiliki prioritas ketiga dengan nilai eigen 0,238

Jadi pemilihan moda transportasi berdasarkan kriteria pelayanan adalah sebagai berikut :

1. Pesawat

2. Kereta api

3. Kapal laut

4. Bus

4. Alernatif Berdasarkan Kriteria Kualitas

Iterasi Ke-1, matriks hasil perbandingan berpasangan berdasarkan kriteria kualitas di kuadratkan sebagai berikut :

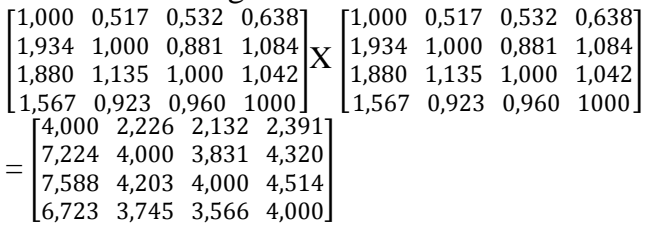

Kemudian menjumlahkan setiap baris matriks perbandingan lalu menghitung nilai eigen untuk normalisasi sebagai berikut :

\begin{tabular}{|c|c|c|c|c|}
\hline \multicolumn{5}{|c|}{ Total Baris Viktor Eigen } \\
\hline 000 & 2,226 & 2,132 & 2,391 & \\
\hline & 4,000 & 3,831 & 4,320 & \\
\hline & 4,203 & 4,000 & 4,514 & 20,3 \\
\hline & 3,745 & 3,566 & 4,000 & $18,3($ \\
\hline
\end{tabular}

Jumlah68, 463

1,000

Dari hasil diatas untuk alternatif berdasarkan kriteria harga dilakukan perhitungan manipulasi matriks perbandingan untuk memenuhi syarat nila eigin tidak berubah 3 angka di belakang koma. Dari viktor eigen tersebut terlihat bahwa sebagai berikut :

a. Bus memiliki prioritas terakhir dengan nilai eigen 0,157

b. Pesawat memiliki prioritas kedua dengan nilai eigen 0,283

c. Kereta Api memiliki prioritas pertama dengan nilai eigen 0,297

d. Kapal Laut memiliki prioritas ketiga dengan nilai eigen 0,263

Jadi pemilihan moda transportasi berdasarkan kriteria pelayanan adalah sebagai berikut :
1. Kereta api
2. Pesawat
3. Kapal laut
4. Bus

5. Alernatif Berdasarkan Kriteria Tujuan Perjalanan
Iterasi Ke-1, matriks hasil perbandingan berpasangan berdasarkan kriteria kualitas di kuadratkan sebagai berikut :

$\left[\begin{array}{llll}1,000 & 0,943 & 0,993 & 0,843\end{array}\right]\left[\begin{array}{llll}1,000 & 0,943 & 0,993 & 0,843 \\ 1,060 & , 000 & 0,824 & 1,018\end{array}\right]$

$\begin{array}{llll}1,060 & 1,000 & 0,824 & 1,018 \\ 1,007 & 1,214 & 1,000 & 0,955\end{array} \times \begin{array}{rrrr}1,000 & 0,943 & 0,993 & 0,843 \\ 1,060 & 1,000 & 0,824 & 1,018\end{array}$

$\left.\begin{array}{rrrr}1,060 & 1,000 & 0,824 & 1,018 \\ 1,007 & 1,214 & 1,000 & 0,955\end{array}\right] \times\left[\begin{array}{rrrr}1,060 & 1,000 & 0,824 & 1,018 \\ 1,007 & 1,214 & 1,000 & 0,955 \\ 1,186 & 0,982 & 1,047 & 1,000\end{array}\right]$

$\left.\begin{array}{lllll}1,186 & 0,982 & 1,047 & 1,000\end{array}\right]\left[\begin{array}{llll}1,060 & 1,000 & 0,824 & 1,018 \\ 1,007 & 1,214 & 1,000 & 0,955 \\ 1,186 & 0,982 & 1,047 & 1,000\end{array}\right]$

$\left[\begin{array}{llll}4,000 & 3,919 & 0,993 & 0,843 \\ 4,195 & 4,000 & 3,767 & 3,717\end{array}\right]$

$=\left[\begin{array}{llll}4,195 & 4,000 & 3,767 & 3,717 \\ 4,434 & 4,315 & 4,000 & 3,994 \\ 4,469 & 4,354 & 4,082 & 4,000\end{array}\right]$

$\left[\begin{array}{llll}4,434 & 4,315 & 4,000 & 3,994 \\ 4,469 & 4,354 & 4,082 & 4,000\end{array}\right]$

Kemudian menjumlahkan setiap baris matriks perbandingan lalu menghitung nilai eigen untuk normalisasi sebagai berikut :

Total Baris Viktor Eigen

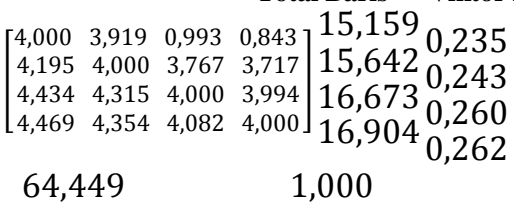

Jumlah $\quad 64,449 \quad 1,000$

Dari hasil diatas untuk alternatif berdasarkan kriteria harga dilakukan perhitungan manipulasi matriks perbandingan untuk memenuhi syarat nila eigin tidak berubah 3 angka di belakang koma. Dari viktor eigen tersebut terlihat bahwa sebagai berikut :

a. Bus memiliki prioritas terakhir dengan nilai eigen 0,235

b. Pesawat memiliki prioritas ketiga dengan nilai eigen 0,243

c. Kereta Api memiliki prioritas kedua dengan nilai eigen 0,260

d. Kapal Laut memiliki prioritas pertama dengan nilai eigen 0,262

Jadi pemilihan moda transportasi berdasarkan kriteria pelayanan adalah sebagai berikut :
1. Kapal laut
2. Kereta Api
3. pesawat
4. Kereta Api

\section{Konsistensi Logis}

Langkah langkah yang dilakukan dalam mengukur konsistensi logis dari data yang telah diolah diatas adalah sebagai berikut:

1. Kriteria Utama

a. Kalikan nilai matrik awal dengan nilai eigen vektor

$\left[\begin{array}{llll}1,000 & 1,523 & 1,154 & 1,747\end{array}\right] \quad[0,326] \quad[1,332$

$\left.\begin{array}{llll}0,657 & 1,000 & 0,935 & 1,084 \\ 0,867 & 1,070 & 1,000 & 1,076 \\ 0,572 & 0,923 & 0,929 & 1,000\end{array}\right] \times\left[\begin{array}{l}0,222 \\ 0,246\end{array}\right]=\left[\begin{array}{l}1,332 \\ 0,875 \\ 0,988 \\ 0,826\end{array}\right]$

$\left[\begin{array}{llll}0,572 & 0,923 & 0,929 & 1,000\end{array}\right] \quad\left[\begin{array}{l}0,206 \\ 0,26\end{array}\right]\left[\begin{array}{l}0,988 \\ 0,826\end{array}\right]$

b. Kemudian hasil perkalian tersebut di bagin dengan nilai viktor eigen

$\left[\begin{array}{l}1,332 \\ 0,875 \\ 0,988 \\ 0,826\end{array}\right],\left[\begin{array}{l}0,326 \\ 0,222 \\ 0,246 \\ 0,206\end{array}\right]=\left[\begin{array}{l}4,086 \\ 3,942 \\ 4,015 \\ 4,010\end{array}\right]$

c. Jumlahkan hasil bagi diatas dengan banyaknya elemen yang ada dan hasilnya disebut $\lambda$ Maksimum

$\Lambda$ maks $+\frac{(4,086+3,942+4,015+4,010)}{4}=\frac{16,052}{4}=4,013$

d. Menghitung Consistency Index (CI)

$$
\begin{aligned}
\mathrm{CI} & =\frac{(4,013-4)}{4-1} \\
& =\frac{0,013}{3}=0,004
\end{aligned}
$$


e. Menghitung Rasio Kosistensi (Consistency Ratio atau CR). Karena disini ada 4 kriteria maka nilai dari IR adalah 0,90

$$
\mathrm{CR}=\frac{0,004}{0,90}=0,005
$$

Karena hasil perhitungan nilai dari $\mathrm{CR} \leq 0,1$, maka perhitungan dapat dikatakan konsisten atau dapat diterima

2. Alternatif Berdasarkan Kriteria Harga

a. Kalikan nilai matrik awal dengan nilai eigen vektor

$\left[\begin{array}{llll}1,000 & 1,538 & 0,928 & 1,358 \\ 0,650 & 1,000 & 0,536 & 0,954\end{array}\right]\left[\begin{array}{l}0,288 \\ 0,186\end{array}\right]\left[\begin{array}{l}1,156 \\ 0,746\end{array}\right.$

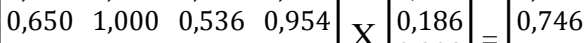

$\left[\begin{array}{llll}1,078 & 1,866 & 1,000 & 1,242 \\ 0,736 & 1,048 & 0,805 & 1,000\end{array}\right] X\left[\begin{array}{l}0,186 \\ 0,308 \\ 0,218\end{array}\right]=\left[\begin{array}{l}0,746 \\ 1,236 \\ 0,873\end{array}\right]$

b. Kemudian hasil perkalian tersebut di bagin dengan nilai viktor eigen

$\left[\begin{array}{l}1,156 \\ 0,746 \\ 1,236 \\ 0,873\end{array}\right],\left[\begin{array}{l}0,288 \\ 0,186 \\ 0,308 \\ 0,218\end{array}\right]=\left[\begin{array}{l}4,014 \\ 4,012 \\ 4,013 \\ 4,005\end{array}\right]$

c. Jumlahkan hasil bagi diatas dengan banyaknya elemen yang ada dan hasilnya disebut $\lambda$ Maksimum

$\Lambda$ maks $+\frac{(4,014+4,012+4,013+4,005)}{4}=\frac{16,044}{4}=4,011$

d. Menghitung Consistency Index (CI)

$$
\begin{aligned}
C I & =\frac{(4,011-4)}{4-1} \\
& =\frac{0,011}{3}=0,004
\end{aligned}
$$

e. Menghitung Rasio Kosistensi (Consistency Ratio atau CR). Karena disini ada 4 kriteria maka nilai dari IR adalah 0,90

$$
\mathrm{CR}=\frac{0,004}{0,90}=0,004
$$

Karena hasil perhitungan nilai dari $\mathrm{CR} \leq 0,1$, maka perhitungan dapat dikatakan konsisten atau dapat diterima.

3. Alternatif Berdasarkan Kriteria Pelayanan

a. Kalikan nilai matrik awal dengan nilai eigen vektor

$\left[\begin{array}{llll}1,000 & 0,478 & 0,557 & 0,925 \\ 2,092 & 1,000 & 0,987 & 1,107 \\ 1,795 & 1,013 & 1,000 & 1,098 \\ 1,081 & 0,903 & 0,911 & 1,000\end{array}\right] \times\left[\begin{array}{l}0,172 \\ 0,301 \\ 0,289 \\ 0,238\end{array}\right]=\left[\begin{array}{l}0,697 \\ 1,210 \\ 1,164 \\ 0,959\end{array}\right]$

b. Kemudian hasil perkalian tersebut di bagin dengan nilai viktor eigen

$$
\left[\begin{array}{l}
0,697 \\
1,210 \\
1,164 \\
0,959
\end{array}\right] /\left[\begin{array}{l}
0,172 \\
0,301 \\
0,289 \\
0,238
\end{array}\right]=\left[\begin{array}{l}
4,044 \\
4,025 \\
4,027 \\
4,032
\end{array}\right]
$$

c. Jumlahkan hasil bagi diatas dengan banyaknya elemen yang ada dan hasilnya disebut $\lambda$ Maksimum

$\Lambda$ maks $+\frac{(4,044+4,025+4,027+4,032)}{4}=\frac{16,128}{4}=4,032$

d. Menghitung Consistency Index (CI)

$$
\begin{gathered}
\mathrm{CI}=\frac{(4,032-4)}{4-1} \\
=\frac{0,032}{3}=0,011
\end{gathered}
$$

e. Menghitung Rasio Kosistensi (Consistency Ratio atau CR). Karena disini ada 4 kriteria maka nilai dari IR adalah 0,90

$$
\mathrm{CR}=\frac{0,011}{0,90}=0,012
$$

Karena hasil perhitungan nilai dari $\mathrm{CR} \leq 0,1$, maka perhitungan dapat dikatakan konsisten atau dapat diterima

4. Alternatif Berdasarkan Kriteria Kualitas

a. Kalikan nilai matrik awal dengan nilai eigen vektor

$\left[\begin{array}{llll}1,000 & 0,517 & 0,532 & 0,638 \\ 1,934 & 1,000 & 0,881 & 1,084 \\ 1,880 & 1,135 & 1,000 & 1,042 \\ 1,567 & 0,923 & 0,960 & 1000\end{array}\right] \times\left[\begin{array}{l}0,157 \\ 0,283 \\ 0,297 \\ 0,263\end{array}\right]=\left[\begin{array}{l}0,629 \\ 1,133 \\ 1,187 \\ 1,055\end{array}\right]$

b. Kemudian hasil perkalian tersebut di bagin dengan nilai viktor eigen

$$
\left[\begin{array}{l}
0,629 \\
1,133 \\
1,187 \\
1,055
\end{array}\right] /\left[\begin{array}{l}
0,157 \\
0,283 \\
0,297 \\
0,263
\end{array}\right]=\left[\begin{array}{l}
4,007 \\
4,005 \\
3,998 \\
4,012
\end{array}\right]
$$

c. Jumlahkan hasil bagi diatas dengan banyaknya elemen yang ada dan hasilnya disebut $\lambda$ Maksimum

$\Lambda$ maks $+\frac{(4,007+4,005+3,998+4,012)}{4}=\frac{16,022}{4}=4,006$

d. Menghitung Consistency Index (CI)

$$
\begin{gathered}
\mathrm{CI}=\frac{(4,006-4)}{4-1} \\
=\frac{0,006}{3}=0,002
\end{gathered}
$$

e. Menghitung Rasio Kosistensi (Consistency Ratio atau CR). Karena disini ada 4 kriteria maka nilai dari IR adalah 0,90

$$
\mathrm{CR}=\frac{0,002}{0,90}=0,002
$$

Karena hasil perhitungan nilai dari $\mathrm{CR} \leq 0,1$, maka perhitungan dapat dikatakan konsisten atau dapat diterima

5. Alternatif Berdasarkan Kriteria Tujuan Perjalanan

a. Kalikan nilai matrik awal dengan nilai eigen vektor

$\left[\begin{array}{llll}1,000 & 0,943 & 0,993 & 0,843 \\ 1,060 & 1,000 & 0,824 & 1,018 \\ 1,007 & 1,214 & 1,000 & 0,955 \\ 1,186 & 0,982 & 1,047 & 1,000\end{array}\right] \times\left[\begin{array}{l}0,235 \\ 0,243 \\ 0,260 \\ 0,262\end{array}\right]=\left[\begin{array}{l}0,943 \\ 0,973 \\ 1,042 \\ 1,052\end{array}\right]$

b. Kemudian hasil perkalian tersebut di bagin dengan nilai viktor eigen

$\left[\begin{array}{l}0,943 \\ 0,973 \\ 1,042 \\ 1,052\end{array}\right] /\left[\begin{array}{l}0,235 \\ 0,243 \\ 0,260 \\ 0,262\end{array}\right]=\left[\begin{array}{l}4,014 \\ 4,005 \\ 4,007 \\ 4,014\end{array}\right]$

c. Jumlahkan hasil bagi diatas dengan banyaknya elemen yang ada dan hasilnya disebut $\lambda$ Maksimum

$\Lambda$ maks $+\frac{(4,014+4,005+4,007+4,0114)}{4}=\frac{16,039}{4}=$ 4,010

d. Menghitung Consistency Index (CI)

$$
\begin{gathered}
\mathrm{CI}=\frac{(4,010-4)}{4-1} \\
=\frac{0,010}{3}=0,003
\end{gathered}
$$

e. Menghitung Rasio Kosistensi (Consistency Ratio atau CR). Karena disini ada 4 kriteria maka nilai dari IR adalah 0,90

$$
\mathrm{CR}=\frac{0,003}{0,90}=0,004
$$

Karena hasil perhitungan nilai dari $\mathrm{CR} \leq 0,1$, maka perhitungan dapat dikatakan konsisten atau dapat diterima. 


\section{HASIL DAN PEMBAHASAN}

Berikut struktur hirarki pembobotan nilai dari masing masing alternatif dan kriteria sebagai berikut

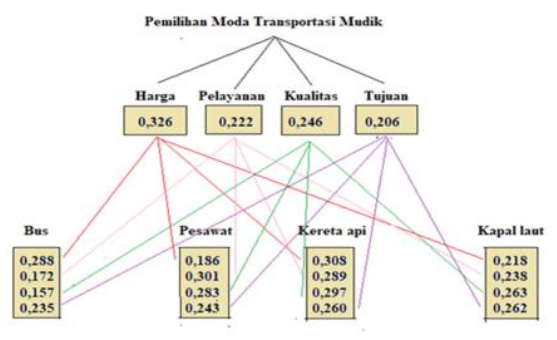

Gambar 3. Gambar Hirarki Hasil Perhitungan

Setelah dilakukan perhitungan data dari kriteria dan juga alternatif selanjutnya dilakukan perhitungan nilai akhir yang mana nilai ini adalah pengabungan dari semuanya dari kriteria dan juga alternatif. Perhitungan untuk nilai akhir diambil dari nilai viktor eigen alternatif berdasarkan kriteria masing masing dikalikan dengan nilai viktor eigen dari kriteria utama dan hasil dari perkalian tersebut disebut dengan nilai viktor eigen keputusan. Berikut adalah cara perhitungan untuk mendapatkan nilai

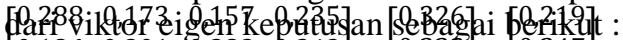
$\begin{array}{llll}0,186 & 0,301 & 0,283 & 0,243 \times \\ 0,308 & 0,289 & 0,222 & 0,260\end{array}=0,247$ $\left.\begin{array}{llll}0,308 & 0,289 & 0,297 & 0,260 \\ 0,218 & 0,238 & 0,263 & 0,262\end{array}\right] \times\left[\begin{array}{l}0,222 \\ 0,246\end{array}\right]=\left[\begin{array}{l}0,247 \\ 0,291 \\ 0,243\end{array}\right]$ $\left[\begin{array}{llll}0,308 & 0,2838 & 0,263 & 0,262\end{array}\right]\left[\begin{array}{l}0,246 \\ 0,206\end{array}\right]\left[\begin{array}{l}0,291 \\ 0,243\end{array}\right]$ Tabel 8. Hasil Akhir Perhitungan

\begin{tabular}{|l|l|}
\hline BUS & 0,219 \\
\hline PESAWAT & 0,247 \\
\hline KERETA API & 0,291 \\
\hline KAPAL LAUT & 0,243 \\
\hline
\end{tabular}

Dari nilai viktor eigen keputusan yangtelah lakukan perhitungan terlihat bahwa :

1. Bus memiliki nilai prioritas terendah dengan nilai eigen 0,219 atau 21,9\%.

2. Pesawat memiliki nilai prioritas kedua dengan nilai eigen 0,247 atau 24,7\%.

3. Kereta Api memiliki nilai prioritas tertinggi dengan nilai eigen 0,291 atau 29,1\%.

4. Kapal laut memiliki nilai prioritas ketiga dengan nilai eigen 0,243 atau 24,4\%.

Selanjutnya yaitu melakukan perhitungan akhir yaitu menghitung Rasio Konsistensi Hirarki (CRH) dengan cara sebagai berikut :

$$
\begin{aligned}
& \mathrm{CRH}=\frac{M}{M \prime} \\
& \text { a. } \quad \mathrm{M}={ }^{M} \text { ' } \mathrm{I} \text { Kriteria }+\left(\text { viktor eigen kriteria) } 0,004 \mathrm{CI}^{\mathrm{I}}\right. \\
& \text { Alternatif) } \\
& =0,004+(0,326 \\
& 0,222 \\
& 0,2460,206) \mathrm{x} \\
& =0,004+0,005 \\
& =0,009 \\
& \text { b. } \left.\quad M^{\prime}=\text { RI Kriteria + (viktor eigen kriteria }\right), 90(R I \\
& \text { alternatif) } \\
& =0,90+(0,326 \\
& =0,90+0,90 \\
& =1,80
\end{aligned}
$$

$$
\begin{aligned}
\text { c. } & \text { Perhitungan } \mathrm{CRH} \\
\text { CRH }=\frac{M}{M^{\prime}} & \\
= & \frac{0,005}{1,80}=0,005
\end{aligned}
$$

Dari perhitungan diatas dapat dilihat bahwa nilai CRH kurang dari 0,1 atau kurang dari $10 \%$, maka dapat dinyatakan bahwa nilai keseluruhan hirarki bersifat konsisten atau dapat diterima sehingga keputusan ditetapkan dapat diandalkan, dan hasil yang diperoleh sesuai dengan hipotesis.

\section{KESIMPULAN}

Dalam mendapatkan hasil atau rancangan untuk menentukan kriteria-kriteria atau alternatif dapat dilakukan studi kasus lapangan dan melakukan wawanara terhadap sampel yang hasilnya terdapat empat kriteria. Empat kriteria tersebuat adalah Harga, Pelayanan, Kualitas, Tujuan Perjalanan. Yang mana natintinya akan menjadi tolak ukut untuk menentukan moda transportasi yang akan dipilih.

Hasil dari penggolahan data menggunakan etode Analytic Hierarchy Process (AHP) di dapatkan bahwa moda transportasi Kereta Api menjadi prioritas pertama dengan $29 \% \%$, dan disusul peringkat kedua ada Pesawat dengan 24,7\% , diperingkat ketiga ada Kapal laut dengan 24,3\% dan terakir ada transportasi Bus dengan 22\%.

\section{REFERENSI}

Basuki, Ari dan Andharini Dwi Cahyani. (2016). Sistem Pendukung Keputusan.Yogyakarta: Deepublish.

Jusna. Tibertius Nempung (2016). Peranan Transportasi Dalam Menunjang Arus Barang dan Orang Di Kecamanatan Maigano Kabupaten Muna. Jurnal Ekonomi I. No.1(April 2016, E-ISSN :2503-1937), 189200. Diambil Dari : http://ojs.uho.ac.id/index.php/JE/article/view/9 $84 / 629$ (29 juli 2019).

Narti. Sriyadi. Nur Rahmayani. Et al (2019). Pengambilan Keputusan Memilih Sekolah Dengan Metode AHP. No. 1 (April 2019, ISSN: $\quad 2355-6579 \quad$ E-ISSN:2528-2247), 143 150 diambil dari https://ejournal.bsi.ac.id/ejurnal/index.php/ji/art icle/view/5552/pdf

Priyono. Lila Dini Utami (2018). Penerapan Metode Analytic Hierarchy process Pada Sistem Keputusan Hasil Diagnosa Penyakit Demam Berdarah. Jurnal Teknik Informatika STMIK Antar Bangsa, IV No.l(Februari 2018, ISSN : 2442-2444), 42-50. Diambil dari : http://ejournal.antarbangsa.ac.id/v1/idex.php.jti /article/view/187 (29 juli 2019).

Septiani, Dian. Fernando B Siahaan (2017). Sistem Penununjang Keputusan Pemilihan Karyawan Berperstasi Dengan Metode Analytical Hierarchy Process (AHP) Pada PT Ichiya Indonesia. Jurnal Teknik Komputer AMIK BSI, III No.1(Febuari 2017, ISSN : 2442-2436), 1-8. 

Diambil Dari
http://ejournal.bsi.ac.id/ejurnal/index.php/jkt/ar
ticle/view/1336 (29 juli 2019)

Sitio, Arjon Samuel (2017). Sistem Pendukung Keputusan Penentuan Suplier Pembelia Barang Menggunakan Metode Analytic Hierarchy Process Pada PT Perintis Sarana Pancing Indonesia. Journal of Informatic Pelita Nusantara II No.1(Oktober 2017, e-ISSN : 2541-3724), 40-47. Diambil Dari : http://ejurnal.pelitanusantara.ac.id/index.php/JIPN/arti cle/view/297 (29 juli 2019)

\section{PROFIL PENULIS}

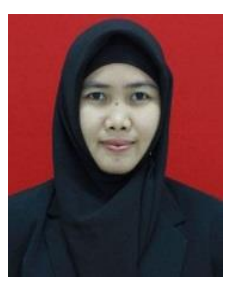

Narti, M.Kom. Tahun 2014 lulus pendidikan Program Strata Satu (S1) Program Studi Sistem Informasi Sekolah Tinggi Manajemen Informatika dan Komputer (STMIK) Nusa Mandiri Jakarta. Tahun 2016 lulus Program Strata Dua (S2) Pascasarjana STMIK Nusa Mandiri dengan konsentrasi bidang Manajemen Information System (MIS). Aktifitas sebagai dosen STMIK Nusa Mandiri Jakarta.

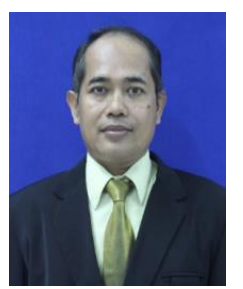

Ahmad Yani, ,MM,M.Kom. Tahun 1998 lulus pendidikan Program Strata Satu (S1) Program Studi Komputerisasi Akuntansi Sekolah Tinggi Manajemen Informatika dan Komputer (STMIK) Budi Luhur Jakarta. Tahun 2003 lulus pendidikan program Strata Dua (S2) program studi Manajemen Pemasaran pada STIE Jakarta dan Tahun 2010 lulus Program Strata Dua (S2) Pascasarjana STMIK Nusa Mandiri dengan konsentrasi bidang Manajemen Information System (MIS). Aktifitas sebagai dosen Universitas Bina Sarana Informatika.

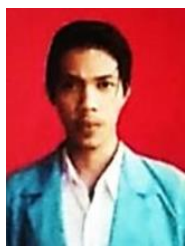

Adika Dharma Setiadi, S.Kom Tahun 2014 lulus pendidikan SMK YPT Purworejo, Tahun 2019 lulus pendidikan program studi Sistem Informasi Sekolah Tinggi Manajemen Informatika Dan Komputer Nusa Mandiri Jakarta. 